University of Nebraska - Lincoln

DigitalCommons@University of Nebraska - Lincoln

Faculty Publications from the Harold W. Manter Laboratory of Parasitology

10-1971

Some Adult Digenetic Trematodes in Striped Mullet from the Northern Gulf of Mexico

Robin M. Overstreet

Gulf Coast Research Laboratory, robin.overstreet@usm.edu

Follow this and additional works at: https://digitalcommons.unl.edu/parasitologyfacpubs

Part of the Parasitology Commons

Overstreet, Robin M., "Some Adult Digenetic Trematodes in Striped Mullet from the Northern Gulf of Mexico" (1971). Faculty Publications from the Harold W. Manter Laboratory of Parasitology. 302. https://digitalcommons.unl.edu/parasitologyfacpubs/302

This Article is brought to you for free and open access by the Parasitology, Harold W. Manter Laboratory of at DigitalCommons@University of Nebraska - Lincoln. It has been accepted for inclusion in Faculty Publications from the Harold W. Manter Laboratory of Parasitology by an authorized administrator of DigitalCommons@University of Nebraska - Lincoln. 


\title{
SOME ADULT DIGENETIC TREMATODES IN STRIPED MULLET FROM THE NORTHERN GULF OF MEXICO*
}

\author{
Robin M. Overstreet \\ Gulf Coast Research Laboratory, Ocean Springs, Mississippi 39564
}

\begin{abstract}
Morphological information is given on the adults of 4 trematodes from Mugil cephalus from estuarine waters of the northern Gulf of Mexico with complementary information from specimens from Georgia. Lasiotocus glebulentus sp. n., from the Gulf, possesses a submedian genital pore and apparently differs from all known species by containing several large concretions in the excretory vesicle. Data are presented for Hymenocotta manteri Overstreet, 1969, Saccocoelioides beauforti (Hunter and Thomas, 1961) comb. n., and Dicrogaster fastigatus Thatcher and Sparks, 1958. These 3 species are now known from both the Gulf of Mexico and the western Atlantic coast. Carassotrema mugilicola Shireman, 1964, is transferred to the genus Chalcinotrema Freitas, 1947.
\end{abstract}

The striped mullet, Mugil cephalus Linnaeus, is a cosmopolitan marine fish found in both fresh and salt waters of the tropical and warm temperate zones. It is a host for a large number of trematodes, many of which were cited by Doss and Farr (1969). In fact, mullet have been theorized by Manter (1957) and others as serving as an ecological bridge between trematodes of freshwater and marine fishes of coastal waters. Four adult species from the northern Gulf of Mexico are discussed below. Two others, Carassotrema mugilicola Shireman, 1964, not recovered by me, and a new species of Lecithaster Lühe, 1901, which will be described by me in a future paper, are also found in striped mullet from the Gulf region.

The trematodes were examined alive, fixed in hot AFA solution under minimal coverslip pressure, and stained with Van Cleave's hematoxylin. Figures, except those designated otherwise, were drawn from mounted material with the aid of a camera lucida. All except the first are of material from the Gulf of Mexico region. Measurements are given in microns.

Family Haplosplanchnidae Hymenocotta manteri Overstreet, 1969

(Figs. 2-5)

Redescription (based on 19 mature mounted specimens from Louisiana and Mississippi and living material from same areas): Body 1,047 to 1,835 long by 208 to 421 wide. Oral disc not lobed,

Received for publication 30 March 1971.

* This study was conducted in cooperation with the Department of Commerce, NOAA, National Marine Fisheries Service, under Public Law 88-309, Project No. 2-85-R.
141 to 198 wide. Acetabulum 145 to 259 long, 152 to 259 wide, 102 to 198 deep (depth based on 4 noneverted suckers). Sucker width ratio $1: 1.0$ to 1.4 . Forebody 14 to $24 \%$ of body length. Papillae numerous on oral disc, acetabulum, and forebody; an extra large contractile papilla on ventral lip of oral disc. Gland cells numerous in lateral bunches anterior to acetabulum; larger more granular cells near and posterior to rear border of acetabulum; ducts from both sets of glands leading anteriorly and opening at large papilla on oral disc. Prepharynx 17 to 40 long. Pharynx 51 to 81 long by 42 to 72 wide. Cecum terminating in hindbody between preovarian and posttesticular levels. Testis 182 to 370 long by 86 to 194 wide. Posttesticular space 7 to $31 \%$ of body length. Cirrus sac present; containing muscular duct often swollen and appearing as internal seminal vesicle and separate prostatic vesicle. Seminal vesicle extending to near seminal receptacle, usually near ovarian level. Genital atrium short. Ovary 65 to 182 long by 58 to 126 wide. Vitellaria occasionally extending from preacetabular region to posterior end of body. Eggs 74 to 91 long by 46 to 58 wide in mounted specimens, 77 to 95 by 47 to 61 in living ones. Excretory vesicle usually bifurcating in posttesticular space, occasionally as far anteriorly as midtesticular level.

Site: Intestine.

Localities: Artificial ponds and Price Lake in Rockefeller Wildlife Refuge, Grand Chenier, Louisiana, and waters of and adjacent to Mississippi Sound, Mississippi.

Specimen deposited: USNM Helm. Coll. No. 71960.

\section{DISCUSSION}

The data above reveal that more variation in the morphology exists than originally described, most of which could be expected. The major differences between the present specimens and those from Biscayne Bay, Florida, the only other locality recorded, are the more uniform cuplike appearance of the oral disc 

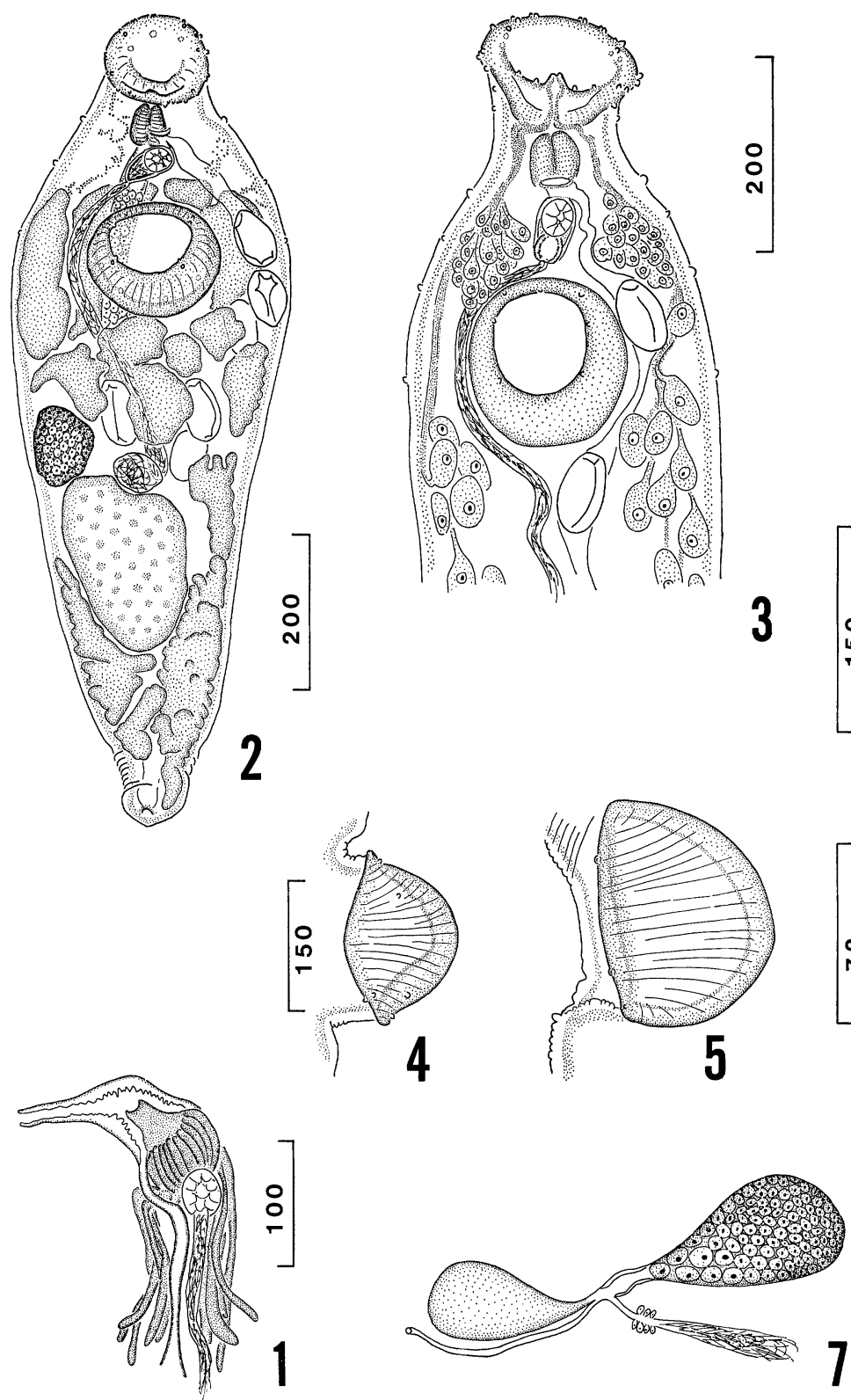
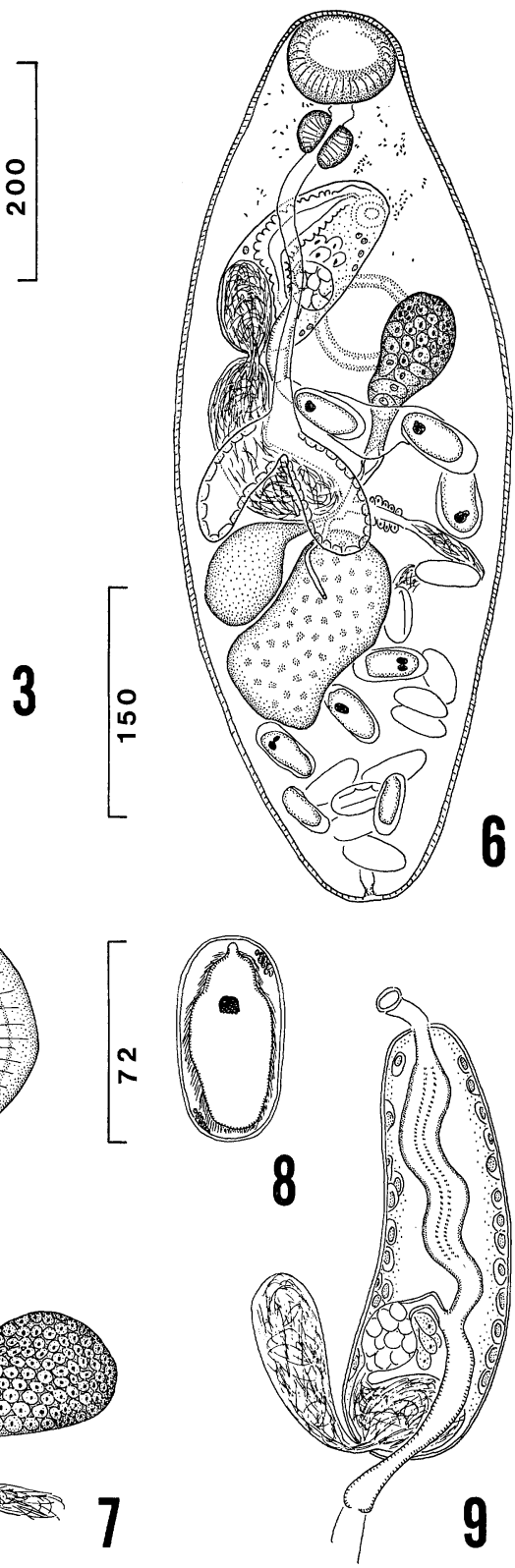

Figure 1. Schikhobalotrema elongatum from Mugil cephalus from Curaçao, region of terminal genitalia.

Figures 2-5. Hymenocotta manteri. 2. Ventral view. 3. Anterior end showing terminal genitalia and gland cells with their ducts, ventral view. 4. Protruded acetabulum, right side view. 5. Acetabulum, not protruded, left side view.

Figures 6-9. Dicrogaster fastigatus. 6. Dorsal view. 7. Ovarian complex. 8. Egg. 9. Hermaphroditic sac. Figures 7-9 drawn freehand from living material. 
and the presence of a cirrus sac, a character of major importance in many trematode groups. Manter noted an inability to observe the sac in all specimens of Hymenocotta mulli Manter, 1961 (see Overstreet, 1969). I believe the forms from Florida and the Gulf of Mexico to be conspecific and the presence of the cirrus sac to further substantiate the position of $H$. manteri in the genus Hymenocotta Manter, 1961, which was erected to accept a species with an oral disc and a cirrus sac. Life history information or additional Atlantic material may indicate that worms from the two areas are valid subspecies or even different species.

Schikhobalotrema elongatum Nahhas and Cable, 1964, from Mugil cephalus at Curaçao is similar to $H$. manteri in most respects but quickly distinguished from it by the presence of tubules filled with a granular substance and associated with the terminal genitalia (Fig. 1). A similar system present in S. acutum (Linton, 1910) and illustrated by Overstreet (1969) can be used to separate S. acutum from S. adacutum (Manter, 1937) in which it is absent. Five specimens of S. adacutum collected from Halichoeres bivittatus (Bloch), the type host, in Biscayne Bay, Florida, by Mr. Martin Goman and myself compare favorably with the original description in most respects. They measured 0.52 to $0.77 \mathrm{~mm}$ long with a sucker width ratio of $1: 1.4$ to 1.7 . The acetabular lobes were conspicuous, but in most specimens the posttesticular space was longer than that between the testis and acetabulum, the forebody was longer than one-half the length of the hindbody, and the vitellaria extended anterior to the acetabulum.

The system where products of two sets of glands are released externally at an oral papilla is also conspicuous in S. acutum. It is present but not as conspicuous in my specimens of $S$. adacutum, S. kyphosi (Manter, 1947), and S. sparisomae (Manter, 1937) and probably occurs in others. I could not distinguish it in Dr. Cable's loaned specimens of $S$. elongatum, but Nahhas and Cable (1964) described a similar arrangement in S. heterocotylum Nahhas and Cable, 1964. Pritchard and Manter (1961) and Yamaguti (1970) reported similar gland cells in species of Schikhobalotrema from Hawaiian fishes to be associated by ducts with the upper digestive tract.

\section{Family Haploporidae \\ Dicrogaster fastigatus Thatcher and Sparks, 1958}

(Figs. 6-9)

Redescription (based on 16 mature mounted specimens from Louisiana and Mississippi and living material from same areas): Body fusiform with elevated acetabular region, 477 to 818 long by 159 to 356 wide. Eyespot pigment dispersed, mostly in forebody. Gland cells large, granular, with short ducts opening externally at tegument near oral sucker and acetabulum and at or near testicular level. Oral sucker 37 to 72 long by 40 to 93 wide. Acetabulum 65 to 121 long by 63 to 126 wide. Sucker width ratio of 11 specimens 1:0.9 to 1.6. Forebody 16 to $30 \%$ of body length. Prepharynx up to $1 / 2$ length of pharynx. Pharynx 30 to 49 long by 33 to 51 wide. Esophagus 67 to 217 long or 1 to 6 times length of pharynx. Intestinal bifurcation at or just posterior to acetabular level. Ceca terminating 38 to $55 \%$ of body length from posterior end. Testis elongated, 79 to 226 long by 63 to 140 wide. Posttesticular space 10 to $46 \%$ of body length. Hermaphroditic sac elongated, sometimes swollen; containing muscular hermaphroditic duct with 2 groups each with 2 long columns of $2-\mu$-long spines, conspicuous prostatic vesicle, prostatic cells, ovoid internal seminal vesicle, and muscular female duct. External seminal vesicle elongated, usually much shorter but occasionally longer than sac, directed anteriorly, posteriorly, or laterally. Genital pore median or submedian, between level of forward edge of acetabulum and slightly more than 1 acetabular length anterior to that sucker. Ovary usually considerably postacetabular but occasionally at acetabular level; dextral, sinistral, or median; 49 to 93 long by 40 to 84 wide. Seminal receptacle not observed. Laurer's canal variable in position. Vitellarium usually elongated, 42 to 100 long by 33 to 84 wide. Eggs with developed oculate miracidia, 36 to 56 long by 18 to 28 wide in mounted specimens, 61 to 81 by 28 to 42 in living ones. Excretory vesicle $\mathrm{Y}$-shaped with a long stem dividing at or near testicular level when extended; reservoir bulb short, at posterior of vesicle; arms short, usually terminating at testicular level; pore terminal.

Data based on 11 mounted specimens from Sapelo Island, Georgia: Body 582 to 1,094 long by 226 to 449 wide. Oral sucker 61 to 93 long by 77 to 107 wide. Acetabulum 70 to 107 by 79 to 109. Sucker width ratio $1: 0.9$ to 1.1 . Forebody 15 to $25 \%$ of body length. Prepharynx usually less than $1 / 2$ length of pharynx. Pharynx 42 to 58 long by 35 to 63 wide. Esophagus up to 7 times longer than pharynx. Ceca terminating in posterior 38 to $55 \%$ of body length. Testis 72 to 203 long by 44 to 128 wide. Posttesticular space 21 to $51 \%$ of body length. Ovary 63 to 116 long by 44 to 91 wide. Vitellarium 65 to 128 long by 51 to 119 wide. Eggs 35 to 51 long by 19 to 26 wide.

Site: Intestine.

Localities: Artificial ponds and Price Lake in Rockefeller Wildlife Refuge, Grand Chenier, Louisiana; waters of and adjacent to Mississippi Sound, 
Mississippi; Biscayne Bay, Florida; and Sapelo Island, Georgia.

Specimen deposited: USNM Helm. Coll. No. 71961.

\section{DISCUSSION}

There is no evidence to indicate the forms from the Atlantic coast and the Gulf of Mexico are not conspecific. The worms from Georgia have an external seminal vesicle less than half the length of the hermaphroditic sac and directed anteriorly, whereas two specimens from Biscayne Bay, Florida, and those from the Gulf show considerable variation in length and position of the vesicle. Dicrogaster fastigatus had previously been reported from Grand Isle, Louisiana, only (Thatcher and Sparks, 1958).

The original description is incomplete but correct. The position of the Laurer's canal is variable and does not necessarily pass between the ceca. Several additions to the description are given above.

Pearson (1968) briefly discussed the presence of genera in four families with either fully embryonated eggs and reduced vitellaria or incompletely developed embryos and abundant vitellaria. He suggested that the former combination with quickly hatching miracidia was an example of parallel evolution of a common adaptation for hosts in intertidal zones to avoid desiccation and rigors of unhatched eggs. Miracidia of $D$. fastigatus often hatch while still in the uterus. It is notable, however, that the other flukes discussed herein from the mullet, a host taken by me primarily from an intertidal marsh habitat with a nearly diurnal tidal periodicity, do not have fully developed miracidia but have adapted by other means; i.e., they have eggs with thicker shells as do nematodes with eggs developing in soil rather than in water.

\section{Saccocoelioides beauforti} (Hunter and Thomas, 1961) comb. $n$.

(Figs. 10-12)

Redescription (based on 27 mature mounted specimens from Louisiana, Mississippi, and Alabama, and living material from Louisiana and Mississippi): Body fusiform, more pointed posteriorly, 458 to 968 long by 152 to 337 wide. Brownish pigment dispersed throughout entire body, denser in anterior portion. Small gland cells opening externally near oral sucker and laterally in middle of forebody. Oral sucker 59 to 109 long by 64 to 102 wide. Acetabulum 63 to 102 long by 70 to 123 wide. Sucker width ratio 1:0.8 to 1.2 . Forebody 26 to $41 \%$ of body length. Prepharynx 12 to 54 long, usually longer than $1 / 2$ length of pharynx. Pharynx 37 to 63 long by 37 to 65 wide. Esophagus usually 3 to 5 times length of pharynx. Intestinal bifurcation at or posterior to acetabular level. Ceca terminating at or anterior to testicular level. Testis 105 to 266 long by 61 to 170 wide, usually longer than wide. Posttesticular space 4 to $23 \%$ of body length. Hermaphroditic sac 72 to 182 long by 54 to 138 wide, elongate to nearly spherical; containing muscular hermaphroditic duct with narrow curved spines, prostatic vesicle, prostatic cells, pars prostatica, internal seminal vesicle, and muscular female duct. External seminal vesicle spherical to club-shaped, either larger or smaller than internal vesicle, directed anteriorly, posteriorly, or laterally. Genital pore median or submedian, roughly midway between acetabulum and pharynx. Ovary 37 to 84 long by 30 to 72 wide. Swelling of oviduct containing sperm. Vitellaria occasionally extending as far anteriorly as acetabulum and well posterior to testis. Eggs 70 to 107 long by 40 to 56 wide in mounted specimens, 77 to 86 by 47 to 57 (and presumably larger) in living ones. Excretory vesicle $\mathrm{Y}$-shaped, usually bifurcating near testicular or ovarian level; arms extending to acetabular level; pore terminal; stem of vesicle containing one, rarely two, prominent excretory concretions.

Data based on 5 mounted specimens from Sapelo Island, Georgia: Body 668 to 982 long by 283 to 337 wide. Oral sucker 81 to 100 long by 102 to 107 wide. Acetabulum 105 to 114 wide. Sucker width ratio $1: 1.0$ to 1.1 . Forebody 30 to $35 \%$ of body length. Prepharynx 19 to 44 long. Pharynx 56 to 70 long by 49 to 63 wide. Esophagus 138 to 240 long. Testis 170 to 257 long by 112 to 180 wide. Posttesticular space 7 to $19 \%$ of body length. Hermaphroditic sac 130 to 210 long by 95 to 130 wide. Ovary 42 to 109 long by 33 to 86 wide. Eggs 76 to 95 long by 49 to 54 wide.

Site: Intestine.

Localities: Artificial ponds and Price Lake in Rockefeller Wildlife Refuge, Grand Chenier, Louisiana; waters of and adjacent to Mississippi Sound, Mississippi; Dauphin Island, Alabama; Sapelo Island, Georgia.

Specimen deposited: USNM Helm. Coll. No. 71962.

\section{DISCUSSION}

There is no evidence from mounted specimens to suggest the specimens from the Gulf of Mexico region differ with those from Georgia or the smaller holotype of Saccocoelium beauforti from North Carolina. There are some differences, however, between my specimens and the original description other than the slightly larger size of some individuals. The acetabulum is occasionally smaller than the oral sucker, a true seminal receptacle was not observed, the vitellaria are occasionally more extensive, and 


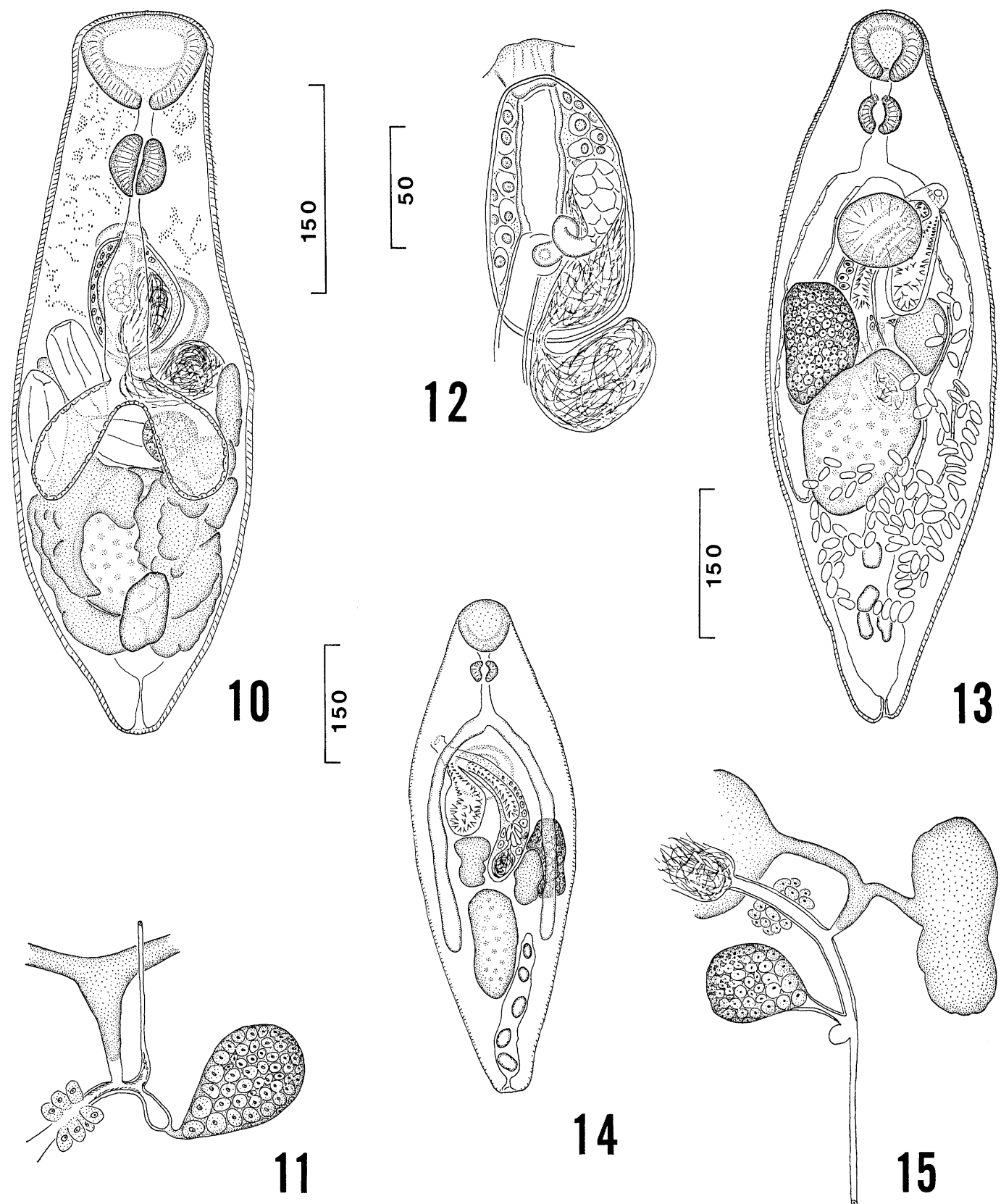

Figures 10-12. Saccocoelioides beauforti. 10. Dorsal view. 11. Ovarian complex drawn freehand from living specimen. 12. Hermaphroditic sac.

Figures 13-15. Lasiotocus glebulentus. 13. Holotype, ventral view. 14. Dorsal view to show cirrus sac and excretory vesicle. 15. Ovarian complex drawn freehand from living specimen showing seminal receptacle at base of oviduct. 
the excretory vesicle excluding the collecting tubules is Y-shaped. A swelling of the oviduct forms a "seminal receptacle" and the interpretation of the excretory vesicle is difficult or impossible in most mounted specimens. If living material from the Beaufort area does not reveal the "seminal receptacle" and excretory vesicle as I have described them, then the Gulf specimens should be considered a distinct species.

The minute spines on the hermaphroditic duct are curved and narrow and usually distinct on living material only. On one mounted worm with an extruded duct, minute papillae were evident but not the spines.

Looss (1902) erected the genus Saccocoelium to accommodate two species with considerably reduced vitellaria and oculate miracidia. Dawes (1947) considered one of those species, S. tensum Looss, 1902, a synonym of the other, S. obesum Looss, 1902, and Fischthal and Kuntz (1963), agreeing with him, considered $S$. beauforti a valid member of the genus. Manter (1963), on the other hand, thought the vitellaria and uterine extent of S. beauforti suggested the species belonged in the genus Skrjabinolecithum Belous, 1954, which has oculate miracidia. I also agree that S. beauforti is placed in the wrong genus. Some of the confusion concerning the validity of genera within the Haploporidae was presented by Lumsden (1963), who considered the present scheme artificial, as do I, until larval stages are studied.

I am tentatively transferring $S$. beauforti to the genus Saccocoelioides Szidat, 1954, as Saccocoelioides beauforti (Hunter and Thomas, 1961) comb. n. Saccocoelioides was considered a subgenus of Lecithobotrys Looss, 1902, by Yamaguti (1958) but accepted by Lumsden (1963). Saccocoelioides beauforti is similar to the type species, S. nanii Szidat, 1954, differing from it primarily by possessing a concretion in the excretory vesicle and slightly more extensive vitellaria. The other species of Saccocoelioides have fewer vitelline follicles and uterine eggs with oculate miracidia and perhaps should not all be in the genus.

Hunter and Thomas (1961) hesitated to erect a new genus for $\mathbf{S}$. beauforti until further species with a prominent excretory concretion and similar distribution of vitellaria were re- corded. Waiting to erect a new genus still appears to be an ideal suggestion since little is known about the biological variation, geographic ranges, and life histories of most species of haploporids, including the waretrematids.

The morphological similarity, including that of the ovarian complex, between S. beauforti and Carassotrema koreanum Park, 1938, from carp in Korea is notable. The two can be differentiated easily by the longer ceca, greater maximum body length, and lack of an excretory concretion in C. koreanum. Another species, $C$. mugilicola Shireman, 1964, from a mullet in Louisiana, is more similar to Chalcinotrema simonei Travassos, Freitas, and Bührnheim, 1965, from a mullet in Brazil, than to Carassotrema koreanum and is therefore considered Chalcinotrema mugilicola (Shireman, 1964) comb. n. Chalcinotrema Freitas, 1947, and Carassotrema Park, 1938, appear to be synonymous, but until evidence such as the shape of the excretory vesicle of members of the former are reported and the morphology the larval stages of both are compared, I prefer to keep them separate. They are primarily freshwater worms from widely separated regions. To illustrate the state of confusion concerning the haploporids, Shireman (1964) suggested Pseudohapladena Yamaguti, 1952, might be a synonym of Carassotrema, and Lumsden (1963) suggested Skrjabinolecithum might be a synonym of Pseudohapladena.

\section{Family Monorchiidae Lasiotocus glebulentus sp. $\mathbf{n}$.}

(Figs. 13-15)

Description (based on 28 mounted specimens, 15 from Alabama including holotype and 13 from Mississippi, plus living material from Mississippi): Body fusiform, usually more pointed at posterior than at anterior end, 458 to 1,124 long by 201 to 310 at widest level (at or above midregion). Tegument spinose; spines more densely situated anteriorly, few within both suckers. Eyespots absent. Oral sucker with ventral aperture, 35 to 79 long by 58 to 102 wide. Acetabulum 60 to 102 long by 67 to 107 wide. Sucker width ratio $1: 1.0$ to 1.3 . Forebody 119 to 275 long or 21 to $34 \%$ of body length. Prepharynx 19 to 56 long. Pharynx 26 to 40 long by 30 to 51 wide. Esophagus 23 to 63 long; both length of prepharynx and esophagus vary between $1 / 2$ and 2 times length of pharynx. Intestinal bifurcation usually nearer level of acetabulum than pharynx. Ceca terminating 6 to $50 \%$ of body length from posterior end, at or beyond testicular level. 
Testis usually irregularly elongate, median, and slightly diagonal; 123 to 233 long by 47 to 119 wide; with vasa efferentia from two anterior lateral margins. Posttesticular space 14 to $43 \%$ of body length. Cirrus sac arcuate, overlapping acetabulum, 180 to 393 long by 37 to 68 wide, 3 to 6 times longer than wide, length 22 to $38 \%$ of body length; containing ovoid seminal vesicle, pars prostatica, vesicular and prostatic cells, and cirrus occupying anterior 45 to $68 \%$ of sac; cirrus with thorn-shaped spines up to $12 \mu$ long with a base up to 15 wide, usually up to 11 long by 8 wide. Genital atrium muscular, without spines, 21 to 35 long. Genital pore sinistral, near anterior edge of acetabulum.

Ovary dextral, contiguous with or somewhat separated from testis, usually postacetabular and not lobed, occasionally at acetabular level or indistinctly lobed, elongated, 44 to 170 long by 28 to 109 wide. Laurer's canal immediately adjacent to small seminal receptacle. Uterus usually filling most of available space posterior to acetabulum, joining midregion of terminal organ or slightly anteriorly. Terminal organ to left of cirrus sac, with spined or unspined basal portion and spined distal portion, 88 to 135 long by 37 to 72 wide, 2 to 3 times longer than wide, length 34 to $69 \%$ of cirrus sac; spines up to 14 long by 8 wide at the base, usually up to 10 by 9 in posterior vesicle, and 6 by 4 in anterior portion. Eggs 16 to 26 long by 9 to 12 wide in mounted specimens, 21 to 30 by 9 to 13 in living ones. Vitellaria tightly compacted in lateral groups at or near ovarian level except in single specimen with separated follicles.

Excretory vesicle elongate, usually extending anteriorly well into testicular level, containing 5 to 13 conspicuous concretions 6 to $63 \mu$ long; pore terminal.

Type host: Mugil cephalus.

Site: Intestine.

Localities: Waters of and adjacent to Mississippi Sound, Mississippi, and Dauphin Island, Alabama.

Holotype: USNM Helm. Coll. No. 71963, paratype: No. 71964 .

The name "glebulentus" refers to the abundance of lumpy concretions in the excretory vesicle.

\section{DISCUSSION}

Lasiotocus glebulentus can apparently be differentiated from all other species of Lasiotocus Looss, 1907, by the several conspicuous concretions in the excretory vesicle. A single conspicuous concretion was present in the vesicles of all but two of 42 reexamined specimens of L. trachinoti Overstreet and Brown, 1970. The present trematode is unusual in having tightly compacted vitellaria and a genital pore to the left of the midline. Most of the numerous species of Lasiotocus have a medially located pore, but in a few it may be either medial or submedial, depending on preparation of the material or biological variation.
Species with a submedial genital pore differ from L. glebulentus in characters other than the excretory concretions. The pore is to the right in L. odhneri (Srivastava, H. D., 1939) Yamaguti, 1954, a species with a sucker width ratio of about 1:0.7 and the terminal organ shaped in an inverted $\mathrm{U}$ anterior to the cirrus sac. In both L. minutus (Manter, 1931) Thomas, 1959, and L. elongatus (Manter, 1931) Thomas, 1959, the genital pore is slightly left of the midline of the acetabulum. The descriptions of both worms are incomplete, but $L$. minutus has an oral sucker larger than the acetabulum and $L$. elongatus has the testis overlapping the ovary, no prepharynx, and slightly separated vitelline follicles. Sogandares-Bernal and Hutton (1959) reported egg sizes of and illustrated a specimen they believed to be L. minutus. In L. mugilis Overstreet, 1969, from the same host at Biscayne Bay, Florida, the genital pore is either medial or submedial, the oral sucker is weakly developed, the ceca consistently extend to near the posterior end of the body, and the eggs are typically smaller, even though overlapping in size with those of L. glebulentus.

The largest mounted paratype and four large solitary L. glebulentus examined alive on 22 February 1971 were devoid of spines in the posterior vesicle and in the proximal portion of the anterior part of the terminal organ. Bartoli (1965) noted a similar condition in L. longicystis where the metacercaria but not the postlarval stage had a spined posterior vesicle and Fischthal and Thomas (1969) reported that some specimens of L. cynoglossi and apparently other species had a spined posterior vesicle while others did not. The taxonomic significance of the presence or absence of the spines is questionable.

\section{ACKNOWLEDGMENTS}

I would like to acknowledge Mr. Wayne E. Swingle of the Department of Conservation, Alabama Marine Resources Laboratory at Dauphin Island, Alabama, for donating living fishes from Alabama and Mr. W. Guthrie Perry of the Louisiana Wild Life and Fisheries Commission for providing fishes and facilities at Rockefeller Wildlife Refuge, Grand Chenier, Louisiana. Specimens of Schikhobalotrema elongatum from Curaçao were lent by Dr. R. M. Cable. Worms cited in the text from Sapelo 
Island, Georgia, were generously donated by Mr. James J. Sullivan. The late Mr. W. W. Becklund of the Beltsville Parasitological Laboratory lent the holotype of Saccocoelium beauforti. Technical assistance was provided by Messrs. Sherman T. Cole and Ronnie G. Palmer.

\section{LITERATURE CITED}

BARToli, P. 1965. Lasiotocus longicystis n. sp. (Trematoda, Digenea, Monorchiidae), métacercaire parasite de lamellibranches marines; recherches expérimentales sur son developpement. Bull. Soc. Zool. France 90: 119-129.

Dawes, B. 1947. The Trematoda of British fishes. Ray Soc., London, 364 p.

Doss, Mildred A., and Marion M. Farr. 1969. Index-catalogue of medical and veterinary zoology, Part 12: hosts: genera M-Z. USDA 378-694.

Fischthal, J. H., AND R. E. Kuntz. 1963. Trematode parasites of fishes from Egypt. Part V. Annotated record of some previously described forms. J. Parasit. 49: 91-98.

—, AND J. D. Thomas. 1969. Digenetic trematodes of marine fishes from Ghana: family Monorchiidae. J. Helm. 43 : 11-30.

Hunter, Wanda S., And L. J. Thomas. 1961. A new species of Saccacoelium (Trematoda, Haploporidae) from Beaufort, N.C. Tr. Am. Micr. Soc. 80: 176-179.

Looss, A. 1902. Die Distomen-Unterfamilie der Haploporinae. Arch. Parasit. 6: 129-143.

LumsDEN, R. D. 1963. Saccocoelioides sogandaresi sp. n., a new haploporid trematode from the sailfin molly Mollienisia latipinna Le Sueur in Texas. J. Parasit. 49: 281-284.

MaNTER, H. W. 1957. Host specificity and other host relationships among the digenetic trematodes of marine fishes. In Premier symposium sur la spécificité parasitaire des parasites de vertebrés. Inst. Zool. Univ. Neuchatel. 185198.

- 1963. Studies on digenetic trematodes of fishes of Fiji, IV. Families Haploporidae, Angiodictyidae, Monorchiidae, and Bucephalidae. Proc. Helm. Soc. Wash. 30: 224-232.

Nahhas, F. M., AND R. M. Cable. 1964. Digenetic and aspidogastrid trematodes from marine fishes of Curaçao and Jamaica. Tulane Stud. Zool. 11: 169-228.

Overstreet, R. M. 1969. Digenetic trematodes of marine teleost fishes from Biscayne Bay, Florida. Tulane Stud. Zool. and Bot. 15: 119176.

Pearson, J. C. 1968. Observations on the morphology and life-cycle of Paucivitellosus fragilis Coil, Reid and Kuntz, 1965 (Trematoda: Bivesiculidae). Parasitology 58: 769-788.

Pritchard, Mary H., AND H. W. Manter. 1961. Studies on digenetic trematodes of Hawaiian fishes: Family Haplosplanchnidae. Proc. Helm. Soc. Wash. 28: 191-197.

Shireman, J. V. 1964. Carassotrema mugilicola, a new haploporid trematode from the striped mullet, Mugil cephalus, in Louisiana. J. Parasit. 50: $555-556$.

Sogandares-Bernal, F., and R. F. Hutton. 1959. Studies on helminth parasites from the coast of Florida. III. Digenetic trematodes of marine fishes from Tampa and Boca Ciega bays. J. Parasit. 45: 337-346.

Thatcher, V. E., and A. K. Sparks. 1958. A new species of Dicrogaster (Trematoda, Haploporidae) from Mugil cephalus in the Gulf of Mexico. J. Parasit. 44: 647-648.

YAMAGUTI, S. 1958. Systema Helminthum. Vol. 1. Digenetic Trematodes of Vertebrates. Interscience Publishers, Inc., New York, 1,575 p.

1970. Digenetic Trematodes of Hawaiian Fishes. Keigaku Publishing Co., Tokyo, $436 \mathrm{p}$. 